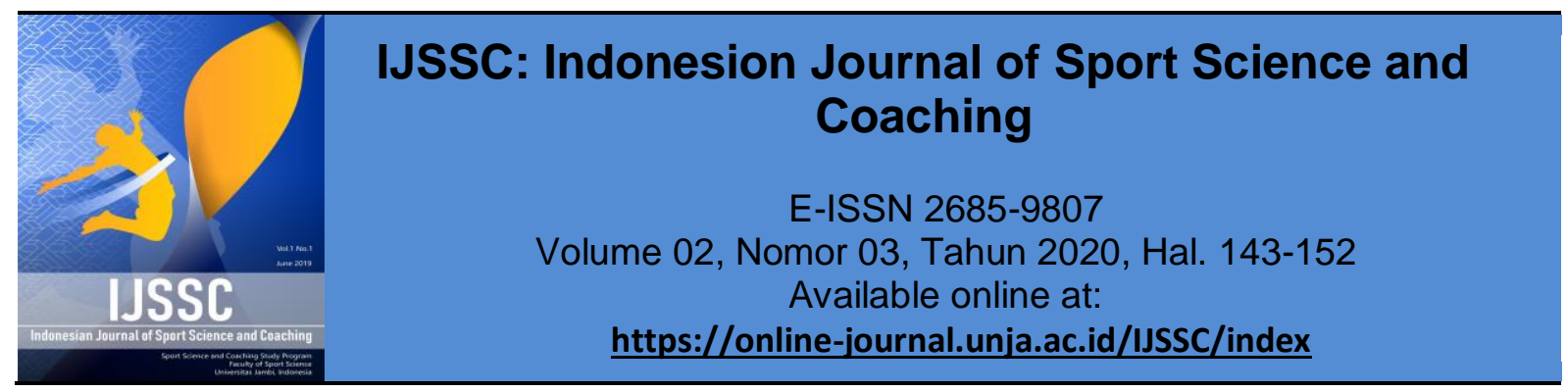

Research Article

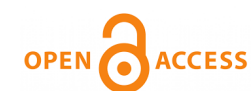

\title{
Tingkat Keterampilan Bermain Bola Voli Pada Unit Kegiatan Mahasiswa Bola Voli Pada Jurusan Olahraga dan Kepelatihan Universitas Jambi
}

\author{
(Volleyball Skill Level In the Volleyball Student Activity Unit In the Sports and Coaching \\ Department Jambi University)
}

\author{
Rasyono*, Iwan Budi Setiawan \\ *Universitas Jambi \\ Jl. Lintas Jambi-Ma.Bulian KM.15 Mendalo Indah, Muaro Jambi-Indonesia \\ Corresponding author: rasyonoiwan12@gmail.com
}

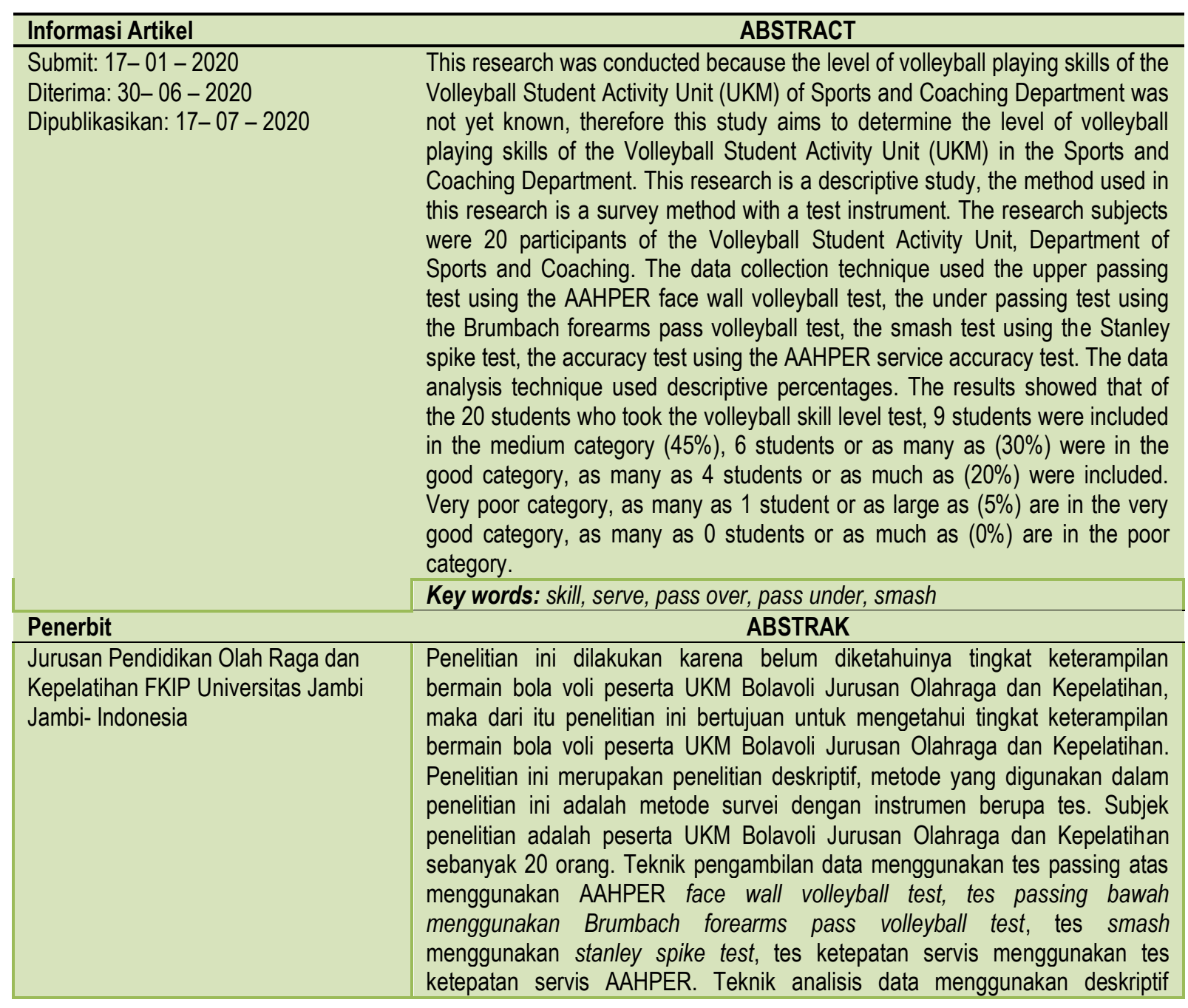


dengan persentase. Hasil penelitian menunjukan bahwa dari 20 siswa yang mengikuti tes tingkat keterampilan bola voli, sebanyak 9 siswa termasuk dalam kategori sedang $(45 \%)$, sebanyak 6 siswa atau sebesar $(30 \%)$ termasuk kategori baik, sebanyak 4 siswa atau sebesar $(20 \%)$ termasuk kategori sangat kurang, sebanyak 1 siswa atau sebesar $(5 \%)$ termasuk kategori sangat baik, sebanyak 0 siswa atau sebesar $(0 \%)$ termasuk kategori kurang.

Kata kunci: keterampilan, servis, passing atas, passing bawah, smash

\section{(c) (1) (2) (2)}

This IJSSC : Indonesian Journal of Sport Science and Coaching is licensed under a CC BY-NCSA (Creative Commons Attribution-ShareAlike 4.0 International License)

\section{PENDAHULUAN}

Permainan bola voli merupakan salah satu cabang olahraga yang sangat digemari masyarakat, tentu hal ini dibuktikan dengan memasyarakatnya olahraga bola voli. Hal ini memang sesuai dengan kesederhanaannya permainan bola voli sehingga masyarakat memilih olahraga bola voli sebagai salah satu cabang olahraga yang digunakan sebagai mengisi waktu luang dalam keseharian. Permainan bola voli juga dapat dimainkan didalam Gedung maupun diluar Gedung, sehingga sangat memberi kemudahan pada masyarakat dalam memainkan olahraga permainan bola voli.

Unit Kegiatan Mahasiswa Jurusan Olahraga dan Kepelatihan Universitas Jambi digunakan untuk mengembangkan bakat, minat dan potensi yang Jurusan Olahraga dan Kepelatihan sesuai dengan karakteristik masing-masing. Unit Kegiatan Mahasiswa di Jurusan Olahraga dan Kepelatihan Universitas Jambi yang diselenggarakan di Jurusan Olahraga dan Kepelatihan memiliki tujuan untuk menciptakan pemain yang berprestasi dan memiliki kecakapan permaianan yang baik dan maksimal.

Unit Kegiatan Mahasiswa Jurusan Olahraga dan Kepelatihan Universitas Jambi melakukan pembinaan bola voli di Jurusan Olahraga dan Kepelatihan secara rutin diselenggarakan empat kali dalam satu minggu. Menurut Nuril Ahmadi (2007: 20) dalam permainan bola voli ada beberapa teknik dasar yang harus dikuasai. Teknik-teknik dalam permainan bola voli terdiri atas servis, passing bawah, passing atas, block, dan smash.

UKM Bola Voli Jurusan Olahraga Dan Kepelatihan UNJA memiliki program latihan empat kali satu minggu, hal ini sudah sangat baik sehingga dimungkinkan para pemain memiliki keterampilan bermain yang baik. Namun demikian belum pernah dilakukan tes keterampilan bermain bola voli pada UKM bola voli Jurusan Olahraga Dan Kepelatihan UNJA, padahal tes seperti ini sangat penting untuk mengetahui tingkat keterampilan para pemain sebagai tolak ukur dan bahan evaluasi dalam menentukan tahapan program jangka panjang.

Dengan demikian perlu diadakannya sebuah penelitian dengan judul "Tingkat Keterampilan Bermain Bola Voli Unit Kegiatan Mahasiswa Jurusan Olahraga dan Kepelatihan Universitas Jambi". Perlunya adanya pembatasan masalah agar menjadi lebih jelas penelitian yang akan dilakukan, dengan demikian pembatasan masalah pada penelitian ini adalah "Tingkat keterampilan bermain bola voli pada Unit Kegiatan Mahasiswa di Jurusan Olahraga dan Kepelatihan Universitas Jambi". Peneitian ini memiliki tujuan untuk mengetahui Tingkat keterampilan bermain bola voli pada Unit Kegiatan Mahasiswa di Jurusan Olahraga dan Kepelatihan Universitas Jambi. Dalam penelitian ini mengutamakan gambaran tingkatan keterampilan bermain bola voli pada Unit Kegiatan Mahasiswa di Jurusan Olahraga dan Kepelatihan Universitas Jambi. Penelitian ini memberikan 
beebrapasumbangan pemikiran tentang tingkat keterampilan bermain pemain, sehingga dapat dijadikan pedoman pembinaan dengan demikian akan di rekomendasi hal-hal sebagai berikut:

a. Tingkat keterampilan bermaian berupada data hasil penelitian.

b. Draf model latihan dalam permainan bola voli

c. Rekomendasi ini akan disampaikan kepada pelatih bola voli pada unit kegiatan Mahasiswa Jurusan Olahraga dan Kepelatihan universitas jambi

Keterampilan merupakan kemampuan yang dilakukan dengan benar sesuai aturan dan penuh kemahiran. Keadaan ini dalapat terjadi jika dilakukan dengan berulang, tentu melalui proses latihan dan pembelajaran. Proses latihan dan pembelajaran yang dilakukan tentu sesuai dengan teori yang benar, sehingga mampu mengahsilkan produk berupa keterampilan yang sesuai dengan yang diharapkan. Banyak pelatih yang melakukan keterampilan dalam bentuk latihan sehingga memang mampu mencapai tingkatan keterampilan yang sesuai. Pada hakekatnya seluruh tugas dalam kehidupan sehari-hari senantiasa melibatkan berbagai keterampilan. Keterampilan itu baru dapat diperoleh apabila dilaksanakan melalui proses pembelajaran atau pelatihan (Amung Ma'mun dan Yudha, 2000: 57-59).

Keterampilan tentu memiliki posisi dan kedudukan diatas kemampuan sehingga membutuhkan komponen yang komplek. Sehingga jelas keterampilan tentu memiliki posisi yang lebih tinggi dari kemampuan. Dengan demikian banyak sekali komponen yang harus dimiliki dalam keterampilan seperti kecepatan, ketepatan sehingganya jelas hal ini sesuai dengan hal yang diharapkan keterampilan. Keterampilan merupakan sebuah derajat yang konsisten dalam mencapai sebuah tujuan yang dilakukan secara efektif dan efisien yang ditentukan oleh kecepatan, ketepatan, bentuk dan kemampuan menyesuaikan diri (Bani Tri Umboro 2009: 13).

Dengan demikian keterampilan bola voli dapat disimpulkan bahwa keterampilan merupakan tingkatan kemampuan dalam melakukan kesesuaian teknik dasar permainan bola voli yang mencangkup item kecepatan, ketepatan, bentuk serta kemampuan dalam menyesuaikan diri. Keterampilan itu sendiri dapat terjadi jika adanya tahapan pembelajaran yang jelas dalam sebuah tahapan latihan.

Permainan bola voli merupakan sebuah permaianan yang melibatkan komponen gerak yang komplek karena memang membutuhkan teknik dasar yang melibatkan kemampuan gerakan dalam memainkan bola dengan keahlian tertentu serta teknik lompatan dalam smash serta bagaimana tubuh bereaksi yang tepat dalam melakukan respon pada setiap bola yang datang. Menurut Nuril Ahmadi (2007: 20) permainan bola voli merupakan suatu permainan yang kompleks yang tidak mudah dilakukan setiap peserta. Sebab, dalam permainan bola voli dibutuhkan koordinasi gerak yang benar- benar bisa diandalkan untuk melakukan semua gerakan yang ada dalam permainan bola voli.

\section{1) Teknik Dasar Permainan Bola Voli}

Dalam permaianan bola voli tentu sama dengan permaianan olahraga pada umumnya. Tentu dalam permainan memerlukan sebuah peraturan dan Teknik yang benar dalam melakukannya, dalam permainan bola voli memiliki beberapa Teknik seperti berikut : servis, passing, smash dan block. 


\section{a) Smash}

Menurut M. Yunus (1992: 69), servis merupakan pukulan pembukaan untuk memulai suatu permainan sesuai dengan kemajuan permainan, teknik saat ini hanya sebagai permukaan permainan, tapi jika ditinjau dari sudut taktik sudah merupakan suatu serangan awal untuk mendapat nilai agar suatu regu berhasil meraih kemenangan.
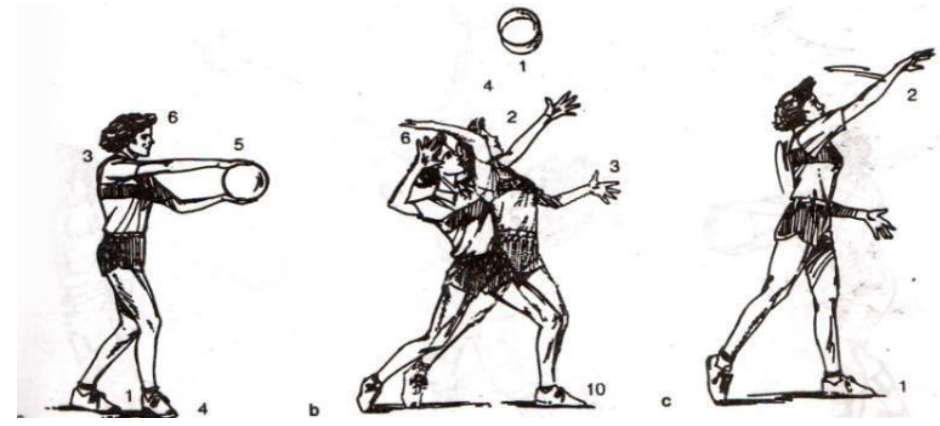

Gambar 1. Rangkaian gerak servis

(Sumber : Barbara L Viera dan Bonnie Jill Fergusson, 2000: 31)

\section{b) Passing}

Passing adalah upaya sepeserta pemain dengan menggunakan suatu teknik tertentu untuk mengoperkan bola yang dimainkannya kepada teman seregunya untuk dimainkan dilapangan sendiri (NurilpAhmadi, 2007: 22). Passing adalah mengoperkan bola kepada teman sendiri dalam satu regu dengan suatu teknik tertentu, sebagai langkah awal untuk menyusun pola serangan kepada regu lawan (M. Yunus, 1992 : 79). Teknik passing dibedakan lagi menjadi dua yaitu teknik passing atas dan teknik passing bawah.
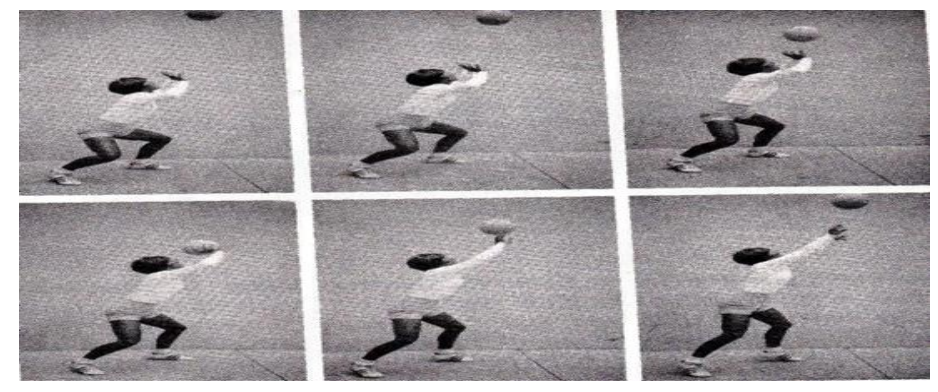

Gambar 2. Teknik Passing Atas

(Sumber : Frances Schaafsma and Ann Heck, 1971: 20)
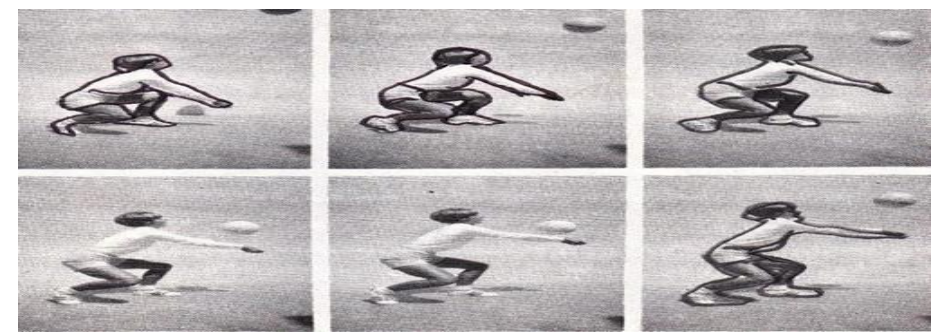

Gambar 3. Teknik Passing Bawah

(Sumber: Frances Schaafsma and Ann Heck, 1971: 1)

c) Smash

Smash adalah pukulan yang utama dalam penyerangan dalam usaha mencapai kemenangan (M. Yunus, 1992 : 108). Sedangkan menurut Nuril Ahmadi $(2007: 31)$ 
smash atau spike adalah pukulan bola yang keras dari atas kebawah, jalannya menukik. Gerakan smash terdiri dari gerak awalan, tolakan untuk meloncat, memukul bola saat melayang di udara, dan mendarat kembali setelah melakukan pukulan.
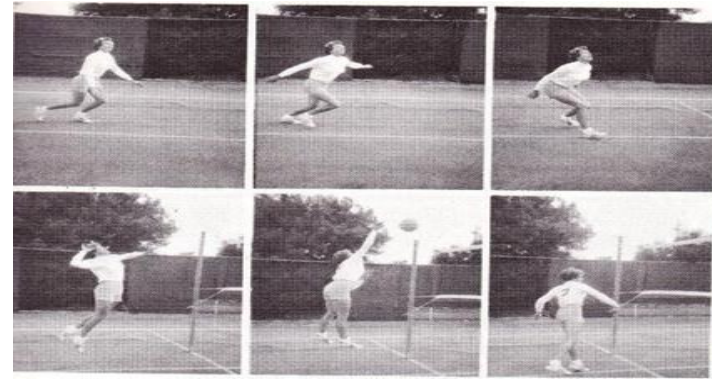

Gambar 4. Teknik smash

(Sumber : Frances Schaafsma and Ann Heck, 1971: 39)

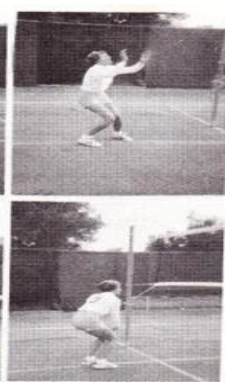

Teknik dalam melakukan permainan bola voli yang terdiri dari teknik dasara pasing, servis dan smas ini merupakan kemampuan yang harus dimiliki pemain bola voli dalam mencapai keterampilan dalam bermain. Sehingga permainan bola voli sangat membutuhkan kemampuan yang mendalam dengan cakupan kemampuan ketepatan, kelincahan serta penguasaan diri.

\section{METODE PENELITIAN}

Penelitian ini menggunakan metode penelitian deskriptif, dimana pada penelitian ini akan diketahui tingkat keterampilan bermain bola voli unit kegiatan Mahasiswa bola voli Jurusan Olahraga dan Kepelatihan universitas jambi. Dengan demikian penelitia akan menggambarkan seberapa besar tingkat keterampilan bermain bola voli pemain. Metode dalam penelitian ini menggunakan metode survey dengan tes. Penelitian dilakukan dengan cara melakukan tes dengan beberapa instrumen tes demi diketahuinya tingkatan keterampilan bermain bola voli, tanpa membuat perbandingan ataupun hubungan antar variabel. Penelitian ini akan dilaksanakan di lapangan bola voli unit kegiatan Mahasiswa Jurusan Olahraga dan Kepelatihan universitas jambi pada bulan april 2019 sampai dengan juli 2020. Sasaran dalam penelitian tingkat keterampilan bermain unit kegiatan Mahasiswa Jurusan Olahraga dan Kepelatihan universitas jambi adalah Mahasiswa dan pelatih Jurusan Olahraga dan Kepelatihan yang mengikuti unit kegiatan Mahasiswa Jurusan Olahraga dan Kepelatihan universitas jambi.

Penelitian ini dilakukan dengan menggunakan data primer dan data skunder, data primer diperoleh dengan observasi dan tes. Sementara data skunder diperoleh dengan analisis hasil dokumentasi.

\section{a. Instrument Pengumpulan Data}

Instrument yang digunakan adalah AAHPER face pass wall-volley test, Brumbach forearm pass wall-volley test, Stanley spike test, dan AAHPER serving accuracy test. Proses pengambilan data di awali dengan memberikan pemanasan kepada peserta, setelah itu peneliti memberi penjelasan dan contoh melakukan AAHPER face pass wall-volley test, Brumbach forearm pass wall-volley test, Stanley spike test, dan AAHPER serving accuracy test, semua itu dilakukan supaya peserta paham dalam pelaksanaan tes dan tidak terjadi kesalahan. Masing-masing peserta mempunyai 1 kali kesempatan untuk tes passing atas selama 1 menit, tes passing bawah selama 1 menit dan tes smash selama 1 
menit, kemudian tes ketepatan servis melewati net dilakukan sebanyak 10 kali kesempatan. Masing-masing peserta mempunyai kesempatan 1 kali tes, ini dilakukan dengan tujuan untuk memperoleh hasil yang benar-benar sesuai dengan kondisi keterampilan bermain bola voli peserta sesungguhnya dengan tanpa adanya perbaikan.

\section{Teknik Analisis Data}

Hasil penelitian menunjukkan data mentah atau kasar, dengan demikian masih dibutuhkan tahapan lanjutan dengan menggunakan penilaian kategori sehingga mundah disimpulkan dan dijelaskan sesuai dengan hasil yang diinginkan. Sedangkan untuk pengkategorian menggunakan acuan 5 batas norma (Anas Sudjono, 2006 : 175).

Setelah diketahui tingkat keterampilan bola voli pada unit kegiatan Mahasiswa Jurusan Olahraga dan Kepelatihan Universitas Jambi yang termasuk kategori: Sangat Baik, Baik, Sedang, Kurang, dan Sangat Kurang , maka akan dapat ditentukan besar persentase dari tiap kategori penilaian. Menurut B. Syarifudin (2010: 112), cara mengubah skor/ nilai ke dalam bentuk persentase, yaitu dengan rumus:

Keterangan :

$\% \quad:$ Persentase

$\sum X \quad$ : Skor $X$ hitung

$\sum$ Maks : Skor maksimal ideal

\section{HASIL PENELITIAN DAN PEMBAHASAN}

Hasil penilaian kemampuan keterampilan bermain bola voli peserta UKM Bolavoli bola voli diperoleh hasil skor minimum sebesar $=39$; skor maksimum $=134$; mean $=86,1$; dan standard deviasi $=26,73$. Deskripsi hasil penilaian keterampilan bola voli UKM Bolavoli, dapat dilihat pada tabel $3 \mathrm{di}$ bawah ini:

Tabel 3. Deskripsi Keterampilan Bermain Bola Voli UKM Bolavoli

\begin{tabular}{|c|c|c|c|c|}
\hline No & Interval & Kategori & Frekuensi & Persentase \\
\hline 1 & $x \geq 126,20$ & Sangat Baik & 1 siswa & $5,00 \%$ \\
\hline 2 & $99,46 \leq X<126,20$ & Baik & 6 siswa & $30,00 \%$ \\
\hline 3 & $72,73 \leq X<99,46$ & Sedang & 9 siswa & $45,00 \%$ \\
\hline 4 & $45,99 \leq X<72,73$ & Kurang & 0 siswa & $0,00 \%$ \\
\hline 5 & $X<45,99$ & Sangat Kurang & 4 siswa & $20.00 \%$ \\
\hline \multicolumn{3}{|c|}{ Jumlah } & 20 siswa & $100 \%$ \\
\hline
\end{tabular}

Apabila ditampilkan dalam bentuk diagram terlihat pada gambar 5 di bawah ini:

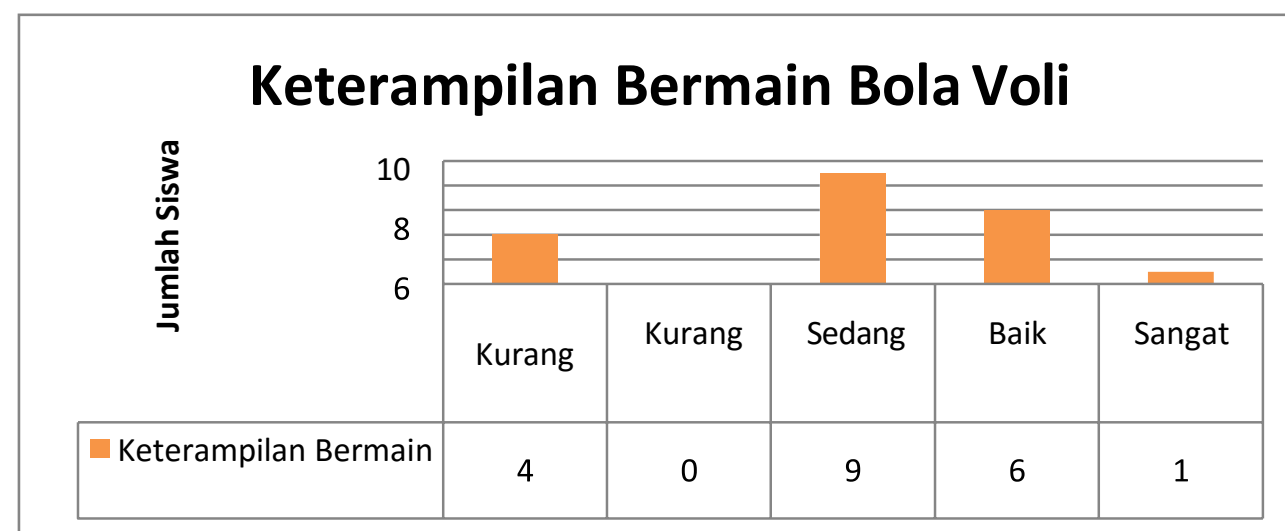


Berdasarkan tabel 3 dan gambar 5 di atas diketahui bahwa keterampilan dasar bermain bola voli UKM Bolavoli, untuk kategori "baik sekali" sebanyak 1 peserta atau sebesar 5,00\%; kategori "baik" sebanyak 6 peserta atau sebesar 30,00\%; kategori "sedang" sebanyak 9 peserta atau sebesar $45,00 \%$; kategori "kurang" sebanyak 0 peserta atau sebesar $00,00 \%$; dan ketegori "kurang sekali" sebanyak 4 peserta atau sebesar $20,00 \%$.

Hasil penilaian keterampilan teknik dasar passing bawah bola voli diperoleh hasil skor minimum sebesar $=9$; skor maksimum $=38$; mean $=24,6$; dan standard deviasi $=8,76$. Deskripsi hasil penilaian keterampilan teknik dasar passing bawah dalam permainan bola voli peserta peserta UKM Bolavoli dapat dilihat pada tabel 4 di bawah ini:

Tabel 4. Deskripsi Keterampilan Teknik Dasar Passing Bawah UKM Bolavoli

\begin{tabular}{|c|c|c|c|c|}
\hline No & Interval & Kategori & Frekuensi & Persentase \\
\hline 1 & $x \geq 37,65$ & Sangat Baik & 1 siswa & $5,00 \%$ \\
\hline 2 & $28,98 \leq X<37,65$ & Baik & 10 siswa & $50,00 \%$ \\
\hline 3 & $20,21 \leq X<28,98$ & Sedang & 2 siswa & $10,00 \%$ \\
\hline 4 & $11,45 \leq X<20,21$ & Kurang & 4 siswa & $20,00 \%$ \\
\hline 5 & $\mathrm{X}<11,45$ & Sangat Kurang & 3 siswa & $15,00 \%$ \\
\hline \multicolumn{3}{|c|}{ Jumlah } & 20 siswa & $100 \%$ \\
\hline
\end{tabular}

Apabila ditampilkan dalam bentuk diagram terlihat pada gambar 6 di bawah ini :

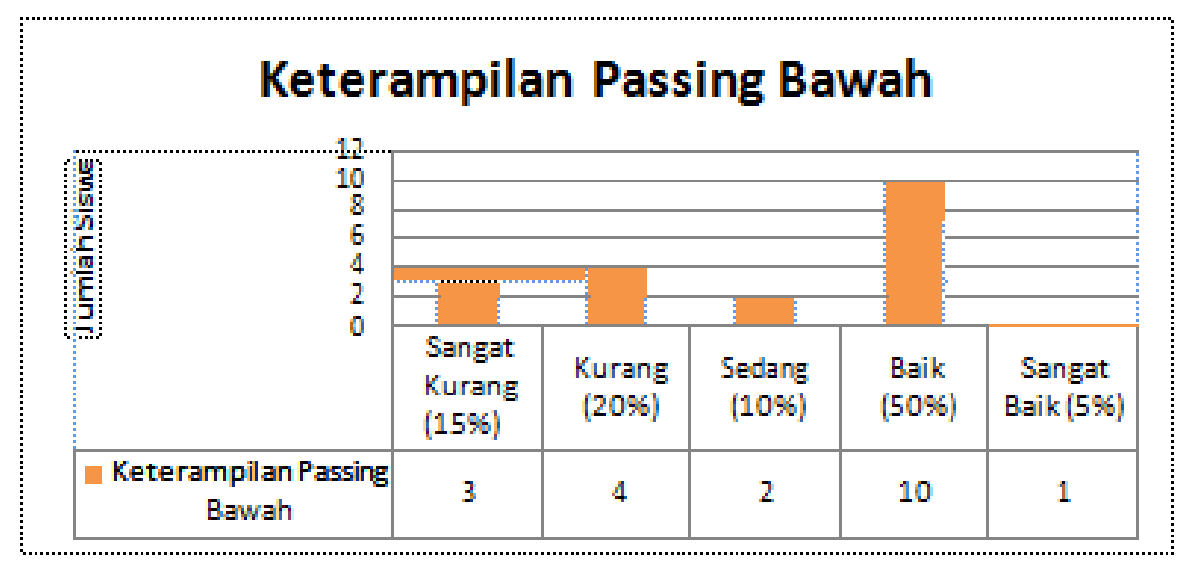

Berdasarkan tabel 4 dan gambar 6 di atas diketahui bahwa keterampilan passing bawah peserta UKM Bolavoli, untuk kategori "sangat baik" sebanyak 1 peserta atau sebesar 5,00\%; kategori "baik" sebanyak 10 peserta atau sebesar 50,00\%; kategori "sedang" sebanyak 2 peserta atau sebesar $10,00 \%$; kategori "kurang" sebanyak 4 peserta atau sebesar 20,00\%; dan ketegori "sangat kurang" sebanyak 3 peserta atau sebesar $15,00 \%$

Hasil penilaian keterampilan passing atas diperoleh hasil skor minimum sebesar $=16$; skor maksimum $=55$; mean $=33$; dan standard deviasi $=10,16$. Deskripsi hasil penilaian keterampilan passing atas UKM Bolavoli, dapat dilihat pada tabel 5 di bawah ini : 
Tabel 5. Deskripsi Keterampilan Passing Atas UKM Bolavoli

\begin{tabular}{|c|c|c|c|c|}
\hline No & Interval & Kategori & Frekuensi & Persentase \\
\hline 1 & $x \geq 48,25$ & Sangat Baik & 1 siswa & $5,00 \%$ \\
\hline 2 & $38,08 \leq X<48,25$ & Baik & 5 siswa & $25,00 \%$ \\
\hline 3 & $27,91 \leq X<38,08$ & Sedang & 9 siswa & $45,00 \%$ \\
\hline 4 & $17,74 \leq X<27,91$ & Kurang & 2 siswa & $10,00 \%$ \\
\hline 5 & $\mathrm{X}<17,74$ & Sangat Kurang & 3 siswa & $15,00 \%$ \\
\hline \multicolumn{3}{|c|}{ Jumlah } & 20 siswa & $100 \%$ \\
\hline
\end{tabular}

Apabila ditampilkan dalam bentuk diagram terlihat pada gambar 7 di bawah ini:

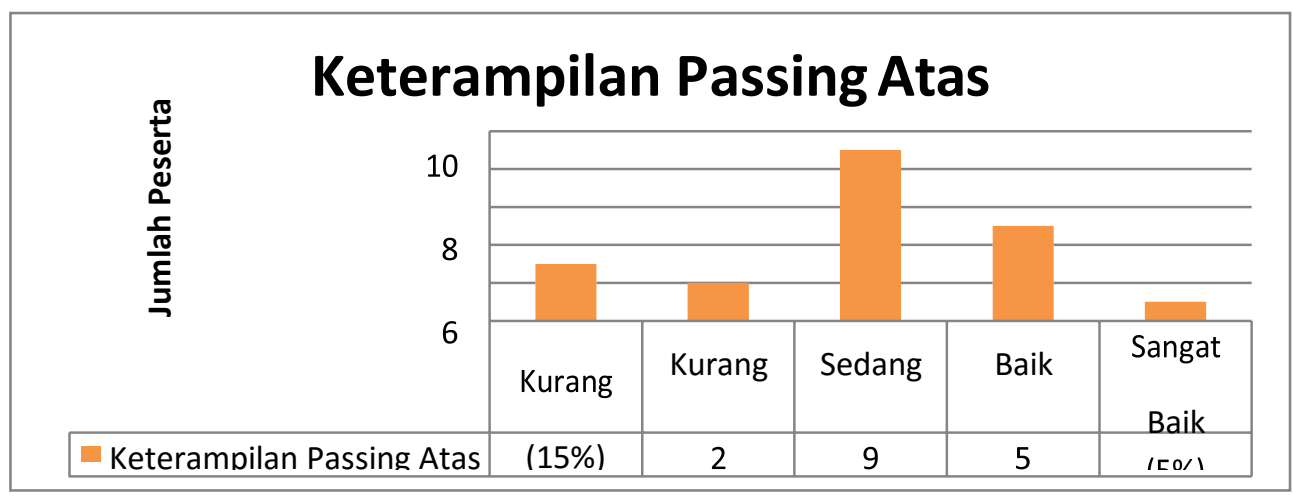

Berdasarkan tabel 5 dan gambar 7 di atas diketahui bahwa keterampilan passing atas UKM Bolavoli, untuk kategori "sangat baik" sebanyak 1 peserta atau sebesar 5,00\%; kategori "baik" sebanyak 5 peserta atau sebesar 25,00\%; kategori "sedang" sebanyak 9 peserta atau sebesar $45,00 \%$; kategori "kurang" sebanyak 2 peserta atau sebesar 10,00\%; dan ketegori "sangat kurang" sebanyak 3 peserta atau sebesar $15,00 \%$.

Hasil penilaian keterampilan smash diperoleh hasil skor minimum sebesar $=4$, skor maksimum $=21$; mean $=14$; dan standard deviasi $=5,53$. Deskripsi hasil penilaian keterampilan smash UKM Bolavoli, dapat dilihat pada tabel 6 di bawah ini:

Tabel 6. Deskripsi Keterampilan Smash UKM Bolavoli

\begin{tabular}{|c|c|c|c|c|}
\hline No & Interval & Kategori & Frekuensi & Persentase \\
\hline 1 & $x \geq 22,29$ & Sangat Baik & 0 siswa & $0,00 \%$ \\
\hline 2 & $16,76 \leq X<22,29$ & Baik & 10 siswa & $50,00 \%$ \\
\hline 3 & $11,23 \leq X<16,76$ & Sedang & 5 siswa & $25,00 \%$ \\
\hline 4 & $5,70 \leq X<11,23$ & Kurang & 2 siswa & $10,00 \%$ \\
\hline 5 & $\mathrm{X}<5,70$ & Sangat Kurang & 3 siswa & $15,00 \%$ \\
\hline \multicolumn{3}{|c|}{ Jumlah } & 20 siswa & $100 \%$ \\
\hline
\end{tabular}


Apabila ditampilkan dalam bentuk diagram terlihat pada gambar 8 di bawah ini :

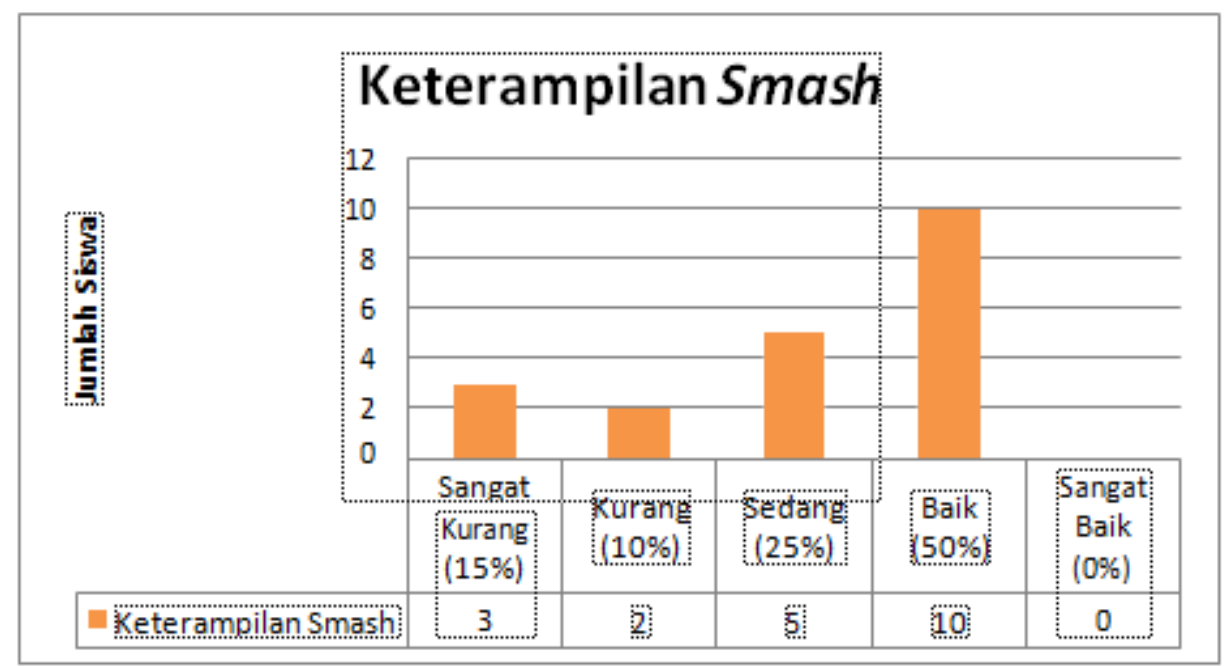

Berdasarkan tabel 6 dan gambar 8 di atas diketahui bahwa keterampilan UKM Bolavoli, untuk kategori "sangat baik" sebanyak 0 peserta atau sebesar 0,00\%; kategori "baik" sebanyak 10 peserta atau sebesar 50,00\%; kategori "sedang" sebanyak 5 peserta atau sebesar 25,00\%; kategori "kurang" sebanyak 2 peserta atau sebesar 10,00\%; dan ketegori "sangat kurang" sebanyak 3 peserta atau sebesar $15,00 \%$.

Hasil penelitian keterampilan servis bola voli UKM Bolavoli diperoleh hasil skor minimum sebesar $=5$; skor maksimum $=28$; mean $=14,5$; dan standard deviasi $=5,93$. Deskripsi hasil penilaian keterampilan servis peserta UKM Bolavoli, dapat dilihat pada tabel 7 di bawah ini :

Tabel 7. Deskripsi Keterampilan UKM Bolavoli

\begin{tabular}{|c|c|c|c|c|}
\hline No & Interval & Kategori & Frekuensi & Persentase \\
\hline 1 & $\mathrm{X} \geq 23,40$ & Sangat Baik & 1 siswa & $5,00 \%$ \\
\hline$\frac{4}{2}$ & $17,46 \leq X<23,40$ & Baik & 4 siswa & $20,00 \%$ \\
\hline 3 & $11,53 \leq X<17,46$ & Sedang & 9 siswa & $45,00 \%$ \\
\hline 4 & $5,59 \leq X<11,53$ & Kurang & 4 siswa & $20,00 \%$ \\
\hline 5 & $x<5,59$ & Sangat Kurang & 2 siswa & $10,00 \%$ \\
\hline \multicolumn{3}{|c|}{ Jumlah } & 20 siswa & $100 \%$ \\
\hline
\end{tabular}

Apabila ditampilkan dalam bentuk diagram terlihat pada gambar 9 di bawah ini

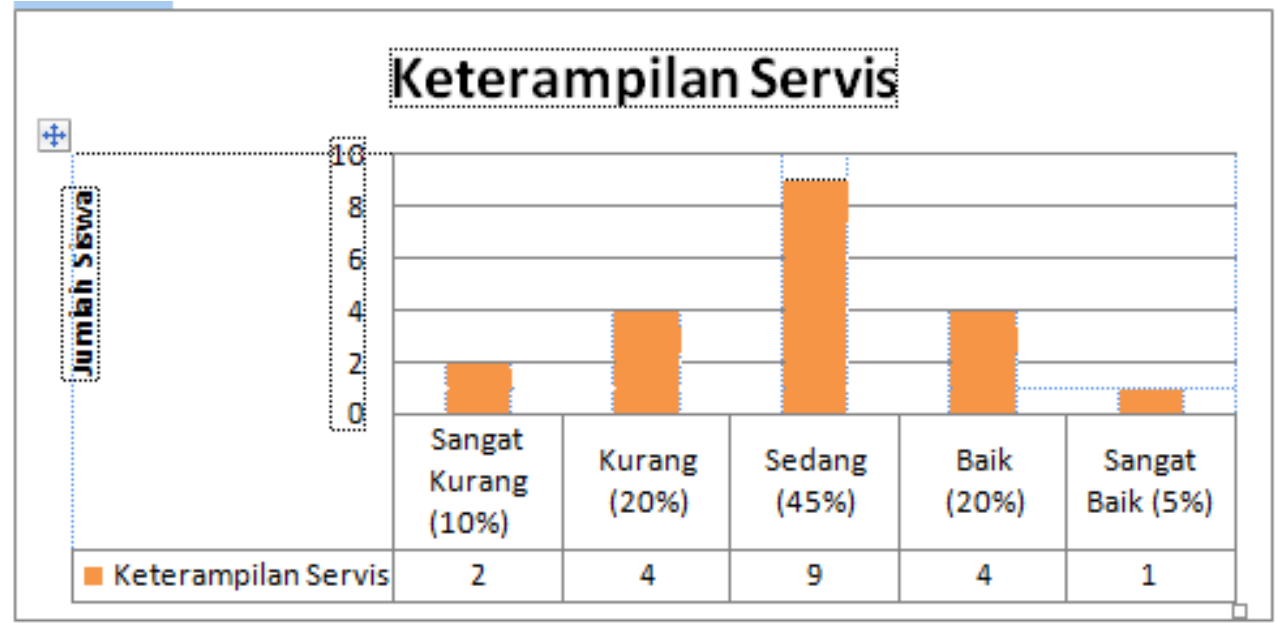


Berdasarkan tabel 7 dan gambar 9 di atas diketahui bahwa keterampilan servis UKM Bolavoli, untuk kategori "sangat baik" sebanyak 1 peserta atau sebesar 5,00\%; kategori "baik" sebanyak 4 peserta atau sebesar $20,00 \%$; kategori "sedang" sebanyak 9 peserta atau sebesar $45,00 \%$; kategori "kurang" sebanyak 4 peserta atau sebesar 20,00\%; dan ketegori "sangat kurang" sebanyak 2 peserta atau sebesar $10,00 \%$.

\section{SIMPULAN}

Berdasarkan hasil penelitian dan pembahasan, dalam penelitian ini peneliti menyimpulkan bahwa dari 20 peserta UKM Bolavoli yang mengikuti tes tingkat keterampilan bola voli sebagian besar masuk dalam kategori "Sedang" sebanyak 9 siswa atau sebesar 45\%, kemudian disusul kategori "Baik" sebanyak 6 siswa atau sebesar 30\%, kemudian kategori "Sangat Kurang" sebanyak 4 siswa atau sebesar 20\%, kategori "Sangat Baik" sebanyak 1 siswa atau sebesar 5\%, dan yang terakhir kategori "Kurang" sebanyak 0 siswa atau sebesar $0 \%$.

\section{RUJUKAN}

M. Yunus. (1992). Olahraga Pilihan Bolavoli. Jakarta: Depdikbud Direktorat Jendral Pendidikan Tinggi.

Nuril Ahmadi. (2007). Panduan Olahraga Bolavoli Surakarta: Pustaka Umum.

Bani Tri Umboro. (2009). Tingkat Keterampilan Bermain Bola voli Peserta Putra Kelas XI Negeri 1 Pundong Bantul. Skripsi. Yogyakarta: Universitas Negeri Yogyakarta.

Amung Ma'mun dan Yudha M. Saputra. (2000). Perkembangan Gerak dan Belajar Gerak. Jakarta: Depdikbud.

Frances Schaafsma and Ann Heck. (1971). Volleyball for Coaches and Teachers. California: WM.C. Brown Company Publishers

Barbara L. Viera dan Bonnie J. Ferguson. (2000). Bolavoli Tingkat Pemula. Jakarta: PT. Raja Grafindo Persada 